\title{
NEW ASPICILIA SPECIES FROM SOUTH KOREA PROVED BY MOLECULAR PHYLOGENY WITH A KEY TO THE EASTERN ASIAN ASPICILIOID LICHENS
}

\author{
Sergii Y. KondratyuK ${ }^{1,2 *}$, László Lőkös ${ }^{3}$, Jung-Sin PARK ${ }^{2}$, Seoul-Hwa JANG ${ }^{2}$, \\ Min-Hae JeONG ${ }^{2}$ and Jae-Seoun HuR ${ }^{2}$ \\ ${ }^{1}$ M. H. Kholodny Institute of Botany, Tereshchenkivska str. 2, 01004 Kyiv-4, Ukraine; *ksya_net@ukr.net \\ ${ }^{2}$ Korean Lichen Research Institute, Sunchon National University, Sunchon 540-742, Republic of Korea \\ ${ }^{3}$ Department of Botany, Hungarian Natural History Museum, H-1431 Budapest, Pf. 137, Hungary
}

Kondratyuk, S. Y., Lőkös, L., Park, J.-S., Jang, S.-H., Jeong, M.-H. \& Hur, J.-S. (2016): New Aspicilia species from South Korea proved by molecular phylogeny with a key to the Eastern Asian aspicilioid lichens. - Studia bot. hung. 47(2): 227-249.

\begin{abstract}
Six species new for science, i.e. Aspicilia pseudoabbasiana, A. pseudovulcanica, A. subepiglypta, A. subgeographica, A. subgoettweigensis, and A. submamillata, are described, illustrated and compared with closely related taxa. A new name Aspicilia abbasiana (for Aspicilia volcanica) and a new combination Rimularia geumodoensis (for Aspicilia geumodoensis) are proposed. Aspicilia cf. pacifica, Buellia coniops, Circinaria contorta, C. leprosescens, Lichenostigma bolacinae, Phaeospora peregrina, and Rosellinula frustulosae are reported for the first time for Korea. A preliminary key to the identification of aspicilioid taxa in the Eastern Asian region is provided.
\end{abstract}

Key words: Circinaria, ITS nrDNA, molecular phylogeny, Rimularia

\section{INTRODUCTION}

Fourteen species of the genus Aspicilia were described by Hue (1912) from Korea based on the Urban Jean (Abbe) Faurie collections more than a century ago. Unfortunately, Hue's results were almost forgotten, and only recently some of his names were recorded in regional checklists (Hur et al. 2005, Moon 2013). A few species of the genus Aspicilia were also added during recent studies (Aptroot and Moon 2014, Kondratyuk et al. 2016a,b). Totally 18 species of the genus Aspicilia have hitherto been recorded for the country.

The aim of this paper is to provide the first results of the taxonomic revision on the Korean representatives of the genus Aspicilia, which have already been proved by molecular study, and to provide a preliminary identification key of aspicilioid taxa in the Eastern Asian region. The revision of the Korean material is still in progress and other results will be published in another addition (see also KONDRATYUK et al. 2016b). 


\section{MATERIAL AND METHODS}

More than 200 specimens previously identified on the generic level as Aspicilia and now deposited in the Korean Lichen Research Institute (KoLRI) (Sunchon, South Korea) were the basic material for our study, while herbarium specimens of $\mathrm{BP}, \mathrm{KW}-\mathrm{L}$, and some other herbaria were included in comparative studies.

Procedures of extracting, sequencing, and phylogenetic analysis are described in our previous papers (KondRATYUK et al. 2015a, b, c, d). Specimens included in the phylogenetic analysis based on ITS nr DNA sequences are listed with GenBank accession numbers in Table 1.

Table 1. Specimens included in analysis with GenBank accession numbers.

\begin{tabular}{|c|c|c|c|}
\hline Name of species & Voucher/Publication & $\begin{array}{l}\text { GenBank acces- } \\
\text { sion number }\end{array}$ & Country \\
\hline Aspicilia abbasiana & $\begin{array}{c}\text { IsMAYIL et al. (2015) as } \\
\text { A. volcanica }\end{array}$ & KM609324 & China \\
\hline Aspicilia blastidiosa & PAUKov et al. (2016) & KX129963 & Russia \\
\hline Aspicilia cinerea & 130634 KoLRI, this paper & KY249596 & South Korea \\
\hline Aspicilia cinerea & 090696 KoLRI, this paper & KY249597 & South Korea \\
\hline Aspicilia cinerea & Ismayil, unpubl. & KT443791 & China \\
\hline Aspicilia cinerea & Nordin et al. (2007) & EU057899 & Sweden \\
\hline Aspicilia cinerea & Roux et al. (2011) & JF710311 & France \\
\hline Aspicilia goettweigensis & PAUKov et al. (2016) & KX159292 & Russia \\
\hline Aspicilia goettweigensis & PAUKOv et al. (2016) & KX159293 & Russia \\
\hline Aspicilia goettweigensis & PAUKov et al. (2016) & KX159289 & Russia \\
\hline Aspicilia pseudoabbasiana & 110218 KoLRI. this paper & KY249598 & South Korea \\
\hline Aspicilia pseudoabbasiana & $\begin{array}{c}140764 \text { KoLRI - holotype, } \\
\text { this paper }\end{array}$ & KY249599 & South Korea \\
\hline Aspicilia pseudoabbasiana & 100188 KoLRI, this paper & KY249600 & South Korea \\
\hline Aspicilia pseudovulcanica & 100584 KoLRI, this paper & KY249601 & South Korea \\
\hline Aspicilia pseudovulcanica & 100698 KoLRI, this paper & KY249602 & South Korea \\
\hline Aspicilia pseudovulcanica & 141375 KoLRI, this paper & KY249603 & South Korea \\
\hline Aspicilia pseudovulcanica & $\begin{array}{c}090722 \text { KoLRI - holotype, } \\
\text { this paper }\end{array}$ & KY249604 & South Korea \\
\hline Aspicilia pseudovulcanica & 100574 KoLRI, this paper & KY249605 & South Korea \\
\hline Aspicilia subdepressa & Roux et al. (2011) & JF703123 & France \\
\hline Aspicilia subepiglypta & 100438 KoLRI, this paper & KY249606 & South Korea \\
\hline Aspicilia subepiglypta & 100857 KoLRI, this paper & KY249607 & South Korea \\
\hline Aspicilia subepiglypta & $\begin{array}{c}110495 \text { KoLRI - holotype, } \\
\text { this paper }\end{array}$ & KY249608 & South Korea \\
\hline
\end{tabular}


Table 1. (continued).

\begin{tabular}{|c|c|c|c|}
\hline Name of species & Voucher/Publication & $\begin{array}{l}\text { GenBank acces- } \\
\text { sion number }\end{array}$ & Country \\
\hline Aspicilia subgeographica & 110813 KoLRI, this paper & KY249609 & South Korea \\
\hline Aspicilia subgeographica & 120356 KoLRI, this paper & KY249610 & South Korea \\
\hline Aspicilia subgeographica & $\begin{array}{l}130359 \text { KoLRI - holotype, } \\
\text { this paper }\end{array}$ & KY249611 & South Korea \\
\hline Aspicilia subgeographica & 110673 KoLRI, this paper & KY249612 & South Korea \\
\hline Aspicilia subgoettweigensis & 120188 KoLRI, this paper & KY249613 & South Korea \\
\hline Aspicilia subgoettweigensis & $\begin{array}{l}130234 \text { KoLRI - holotype, } \\
\text { this paper }\end{array}$ & KY249614 & South Korea \\
\hline Aspicilia subgoettweigensis & 100588 KoLRI, this paper & KY249615 & South Korea \\
\hline Aspicilia subgoettweigensis & 070103 KoLRI, this paper & KY249616 & South Korea \\
\hline Aspicilia subgoettweigensis & 130489 KoLRI, this paper & KY249617 & South Korea \\
\hline Aspicilia submamillata & $\begin{array}{l}090631 \text { KoLRI - holotype, } \\
\text { this paper }\end{array}$ & KY249618 & South Korea \\
\hline Aspicilia submamillata & 091073 KoLRI, this paper & KY249619 & South Korea \\
\hline Aspicilia submamillata & 091096 KoLRI, this paper & KY249620 & South Korea \\
\hline Aspicilia submamillata & 150737 KoLRI, this paper & KY249621 & South Korea \\
\hline Circinaria contorta & IVANOVA and HAFELLNER (2002) & AF332109 & Austria \\
\hline Circinaria contorta & IVANOVA and HAFELLNER (2002) & AF332108 & Austria \\
\hline Circinaria contorta & Nordin et al. (2007) & EU057900 & Sweden \\
\hline Circinaria contorta & SCHMULL et al. (2011) & HQ650638 & USA \\
\hline Rimularia badioatra & RESL et al. (2015) & KR017116 & Sweden \\
\hline Rimularia geumodoensis & 100632 KoLRI, this paper & KY249622 & South Korea \\
\hline Rimularia geumodoensis & $\begin{array}{l}160416 \text { KoLRI - isotype, } \\
\text { this paper }\end{array}$ & KY249623 & South Korea \\
\hline Rimularia geumodoensis & $\begin{array}{l}160406 \text { KoLRI - holotype, } \\
\text { this paper }\end{array}$ & KY249624 & South Korea \\
\hline Rimularia geumodoensis & $090763 \mathrm{KoLRI}$, this paper & KY249625 & South Korea \\
\hline Rimularia geumodoensis & $\begin{array}{l}160418 \text { KoLRI - isotype, } \\
\text { this paper }\end{array}$ & KY249626 & South Korea \\
\hline Rimularia geumodoensis & $161303 \mathrm{KoLRI}$, this paper & KY249627 & South Korea \\
\hline Rimularia gibbosa & ReSL et al. (2015) & KR017107 & USA \\
\hline Rimularia gibbosa & RESL et al. (2015) & KR017111 & USA \\
\hline Rimularia gibbosa & ReSL et al. (2015) & KR017129 & Austria \\
\hline Rimularia intercedens & ReSL et al. (2015) & KR017119 & Austria \\
\hline Rimularia intercedens & ReSL et al. (2015) & KR017134 & Sweden \\
\hline Rimularia limborina & SPRIBILLE et al. (2014) & KJ462273 & USA \\
\hline Rimularia limborina & ReSL et al. (2015) & KR017108 & Norway \\
\hline
\end{tabular}




\section{RESULTS AND DISCUSSION}

Taxa characterised by unique complex of morphological and anatomical characters, and taxa found to have support from molecular data after phylogenetic analysis based on ITS nrDNA sequences, as well as taxa for which we were not able to find proper existing names are described below. Aspicilia cinerea (L.) Körb. previously reported from South Korea is confirmed by molecular data for the first time.

\section{Description of taxa}

Aspicilia pseudoabbasiana S. Y. Kondr., L. Lőkös et J.-S. Hur, sp. nov. (Fig. 1)

MycoBank nr.: MB 819350.

Similar to Aspicilia abbasiana, but differs in having narrower ascospores.

Type: Republic of Korea. Jeju-do, Jeju-si, Chuja-do, Chuja-myeon, Yecho-ri, Mt Dondae, on rock, growing together with Buellia cf. spuria, Lecanora oreinoides, and Caloplaca subconcilians. Lat.: $33^{\circ} 56^{\prime} 53.9^{\prime \prime}$ N, Long.: $126^{\circ} 19^{\prime} 26.7^{\prime \prime}$ E, Alt.: ca $164 \mathrm{~m}$ a.s.l. Leg.: Joshi, Y. and So, J. E. (140764), 20.06.2014 (holotype: KoLRI 023239).

Thallus to $3(-5) \mathrm{cm}$ diam., but may form larger aggregations, dark grey or lead-grey to dark lead-grey, areolate, somewhat shiny, while upper surface dull; areolae (0.5-) 0.7-1.5 mm diam./across, very irregular; rather thick, to 0.35-0.4 $(-0.5) \mathrm{mm}$ thick in section, somewhat scattered in peripheral zone; cortical layer to $15-20 \mu \mathrm{m}$ thick, upper portion more or less brownish or greyish, paraplectenchymatous, cell lumina to 5-7 $\mu \mathrm{m}$ across, $\mathrm{K}$-, with epinecral zone to $10 \mu \mathrm{m}$ thick (better seen in $\mathrm{K}$ ); algal zone $\mathrm{K}+$ yellow, reaction rather weak; algal cells ca 10-16(-22) $\mu \mathrm{m}$ diam.; medulla I-. Hypothallus not observed.

Apothecia (0.4-)0.5-1(-1.2) $\mathrm{mm}$ diam./across and to $0.25-0.3(-0.4) \mathrm{mm}$ thick in section, lecanorine, 1-2(-3) per areole, disc immersed into thallus, black, thalline margin well developed, often thickened and highly uplifted above disc level; hymenium to (100-)110-140 $\mu \mathrm{m}$ high; epihymenium dull greenish, $\mathrm{K}$ - becoming lighter and brownish, $\mathrm{N}+$ distinctly bluish/greenish; subhymenium to $60-70 \mu \mathrm{m}$ thick, hyaline or sometimes dull yellow, with oil droplets; asci 8-spored; ascospores hyaline, simple, widely ellipsoid to widely fusiform with more or less attenuated ends, (15-)17-22(-27) $\times(6.5-) 8-12(-14) \mu \mathrm{m}$; conidiomata to (60-)90-130 $\mu \mathrm{m}$ diam., and to $200 \mu \mathrm{m}$ high; conidia cylindrical, straight, long and narrow, 13-17(-19) $\times 0.7-0.8 \mu \mathrm{m}$. 
Chemistry: Thallus $\mathrm{K}-$ or $\mathrm{K}+$ yellow, medulla $\mathrm{K}+$ yellow. Containing stictic acid (HPLC).

Ecology: Growing on siliceous rocks of coastal zone.

Distribution: So far known from scattered localities of South Korea.

Etymology: It is named after its similarities with the species Aspicilia abbasiana S. Y. Kondr., L. Lőkös, Ismayil et Guo.

Taxonomic notes: Aspicilia pseudoabbasiana is similar to A. abbasiana, but differs in having narrower ascospores.

Aspicilia pseudoabbasiana is similar to $A$. adamanticola Hue, but differs in having dark thallus (vs. light grey), and in having narrower ascospores ((15-)17$22(-27) \times(6.5-) 8-12(-14) \mu \mathrm{m}$ vs. $16-22 \times 12-14 \mu \mathrm{m})$.

The other taxa differ in having different measurements of ascospores as well as in having medulla $\mathrm{K}+$ yellowish reaction and in containing norstictic acid.

Aspicilia pseudoabbasiana is similar to $A$. tofacea Hue, but differs in having dark thallus (vs. whitish grey or white), in having larger thalline areolae (0.7-1.5 $\mathrm{mm}$ vs. $0.3-0.6 \mathrm{~mm}$ across), in having larger apothecia $(0.5-1 \mathrm{~mm}$ vs. $0.2-0.3 \mathrm{~mm}$ diam.) and in having medulla $\mathrm{K}+$ yellow, while ascospores are almost the same ((15-)17-22(-27) × (6.5-)8-12(-14) $\mu \mathrm{m}$ vs. 13-24×10-12 $\mu \mathrm{m})$.

Aspicilia pseudoabbasiana is similar to $A$. arizonica Owe-Larss. et A. Nordin, recently described from North America, but differs in having lower hymenium (110-140 $\mu \mathrm{m}$ vs. (130-)150-200 $\mu \mathrm{m})$, in having narrower ascospores ((15-)17-22 $(-27) \times(6.5-) 8-12(-14) \mu \mathrm{m}$ vs. $(15-) 19-26(-29) \times(9-) 11-16(-21) \mu \mathrm{m})$, as well as in the lack of norstictic (major) and connorstictic (trace) acids. Unfortunately data on ITS sequences of $A$. arizonica (specimens Owe-Larsson 8763 and OweLarsson 8762) are still unavailable for wide access, while authors (LARsson et al. 2004) have mentioned only similarities of $A$. arizonica and $A$. knudsenii, and no Hue's taxa or any Eastern Asian taxa were included in the comparison.
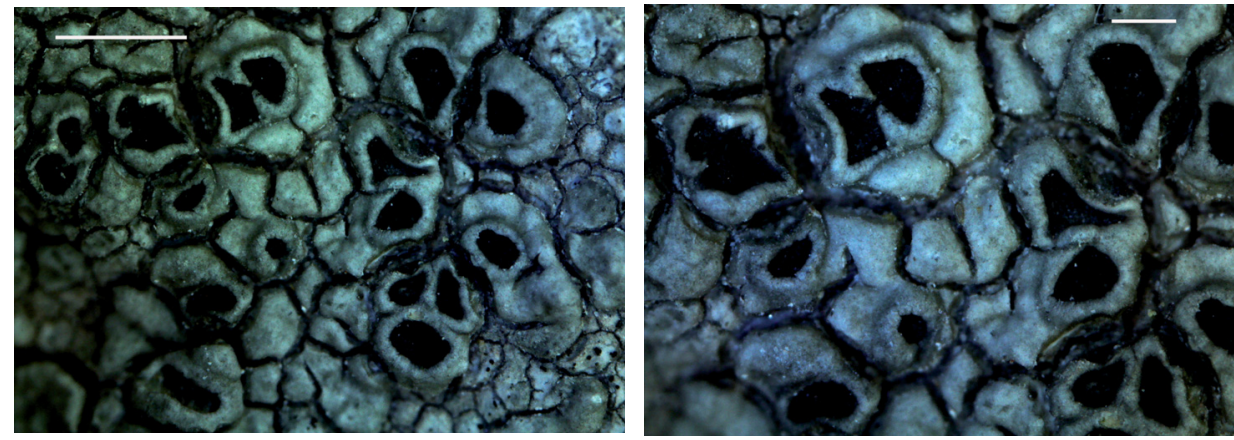

Fig. 1. Aspicilia pseudoabbasiana (holotype, KoLRI 018579), general habit (left) and enlarged portion with apothecia (right). Scale $1 \mathrm{~mm}$ (left) and $0.5 \mathrm{~mm}$ (right). (Photo: S. Y. Kondratyuk). 
Additional specimens examined: Republic of Korea. Gyeongnam-do Prov., Namhae-gun County, seaside, on rock. Lat.: $34^{\circ} 48^{\prime} 51.18^{\prime \prime} \mathrm{N}$, Long.: $127^{\circ} 49^{\prime}$ 41.88” E, Alt.: ca 2 m a.s.l. Leg.: Wang, X. Y. and Ryu, J. A. (110218), 28.04.2011 (KoLRI 013432). - Jeollanam-do, Wando-gun, Bogil myeon, Bogil-do Island, Tong-ri, near Tongri Beach, on rock, growing together with Buellia cf. coniops (Ach.) Th. Fr.*, and Acarospora sp. Lat.: 34 9' 28.05” N, Long.: $126^{\circ} 35^{\prime} 9.00^{\prime \prime}$ E, Alt.: ca 3 m a.s.l. Leg.: Joshi, Y., Jeon, H. S. and Jeong, M.-H. (100188), 06.02.2010 (KoLRI 011688 sub Aspicilia).

Aspicilia pseudovulcanica S. Y. Kondr., L. Lőkös et J.-S. Hur, sp. nov. (Fig. 2)

MycoBank nr.: MB 819351.

Similar to Aspicilia vulcanica, but differs in having larger apothecia and wider ascospores.

Type: Republic of Korea. Gangwon-do, Hongcheon-gun, Nae-myeon, Mt Eungbok, Tongbaram Valley, on rock. Lat.: $37^{\circ} 51^{\prime} 41.5^{\prime \prime} \mathrm{N}$, Long.: $128^{\circ} 31^{\prime} 31.3^{\prime \prime} \mathrm{E}$, Alt.: ca $705 \mathrm{~m}$ a.s.l. Leg.: Joshi, Y., Wang, X. Y. and Ryu, J. A. (090722), 23.05.2009 (holotype: KoLRI 010391).

Thallus 5-10 cm diam., areolate or only slightly cracked to continuous, very thin, to $0.15(-0.3) \mathrm{mm}$ thick in section, whitish grey or light grey; areolae $0.5-1.5$ (-2) mm diam./across; in section thallus to $150-200(-270) \mu \mathrm{m}$ thick, cortical layer to $20-25 \mu \mathrm{m}$ thick, hyaline in upper portion, paraplectenchymatous, cell lumina 7-8 $\mu \mathrm{m}$ diam./across; algal layer $\mathrm{K}+$ yellow (if section rather thick), or weakly yellow (in thin section sometimes hardly observed), algal cells ca 14-20(25) $\mu$ m diam.; medulla I-; lower portion of thallus (medulla below of algal zone) with numerous crystals not dissolving in $\mathrm{K}$. Hypothecium well developed, black, to $0.5-0.8 \mathrm{~mm}$ wide in peripheral zone as entire circle around thallus.

Apothecia $0.5-0.9 \mathrm{~mm}$ diam./across and to $0.13(-0.3) \mathrm{mm}$ thick in section, aspicilioid, immersed, disc concave seems to have white pruina, whitish blackish while at larger magnification greyish or greyish black; thalline edge somewhat hanging above deeply concave disc (seems to be thelotrematoid-like apothecium), often white and well contrasting to grey thallus; in section seems to be lecanorine; true exciple to $25-30 \mu \mathrm{m}$ wide in lateral portion; hymenium to (80-)110-130 $\mu \mathrm{m}$ tall, often with oil droplets to $8 \mu \mathrm{m}$ diam.; epihymenium dirty greenish brown, $\mathrm{K}$ - becoming lighter and brownish, $\mathrm{N}+$ bluish/greenish; subhymenium to $40-50 \mu \mathrm{m}$ thick, with oil droplets to 5-8 $\mu \mathrm{m}$ diam. or often in irregular aggregations; paraphyses to 5-6 $\mu \mathrm{m}$ wide towards the tips, brownish and moniliform; asci 8-spored; ascospores hyaline, simple, widely ellipsoid, 18-

\footnotetext{
* Buellia coniops is reported for the first time from Korea.
} 
$23(-25) \times(9-) 10-12(-14) \mu \mathrm{m}$, if spherical to $12(-15) \mu \mathrm{m}$ diam. Conidiomata and conidia not seen.

Chemistry: Epihymenium $\mathrm{K}$ - brown (green shade disappearing), $\mathrm{N}$ - or intensifying green, sometimes $\mathrm{N}+$ bluish green. Containing stictic acid (HPLC).

Ecology: Growing on siliceous rocks, from coastal zone to high localities in mountains.

Distribution: So far known from scattered localities of South Korea.

Etymology: It is named after its similarities with the species Aspicilia vulcanica Hue.

Taxonomic notes: Aspicilia pseudovulcanica is similar to $A$. vulcanica, but differs in having larger apothecia and wider ascospores.

Additional specimens examined: Republic of Korea. Gangwon-do, Pyeongchang-gun, Jin-bu-myeon, Suhang-ri, Mt Duta (Mt Bakji), on rock. Lat.: $37^{\circ} 33^{\prime}$ 56.6” N, Long.: $128^{\circ} 35^{\prime} 1.5^{\prime \prime}$ E, Alt.: ca $720 \mathrm{~m}$ a.s.l. Leg.: Wang, X. Y., Jeon, H. S., Lü, L. and Ryu, J. A. (100698), 27.05.2010 (KoLRI 012420). - Gangwon-do, Chuncheon-si, Buksan-myeon, Jogyo-ri, Mt Maebong, on rock, growing together with Lecania sp. Lat.: $37^{\circ} 54$ ' 38.28” N, Long.: $127^{\circ} 58^{\prime} 54.48^{\prime \prime} \mathrm{E}$, Alt.: ca $610 \mathrm{~m}$ a.s.l. Leg.: Wang, X. Y., Jeon, H. S., Lü, L. and Ryu, J. A. (100574), 26.05.2010 (KoLRI 012329 sub Aspicilia); the same locality, growing together with Lecania

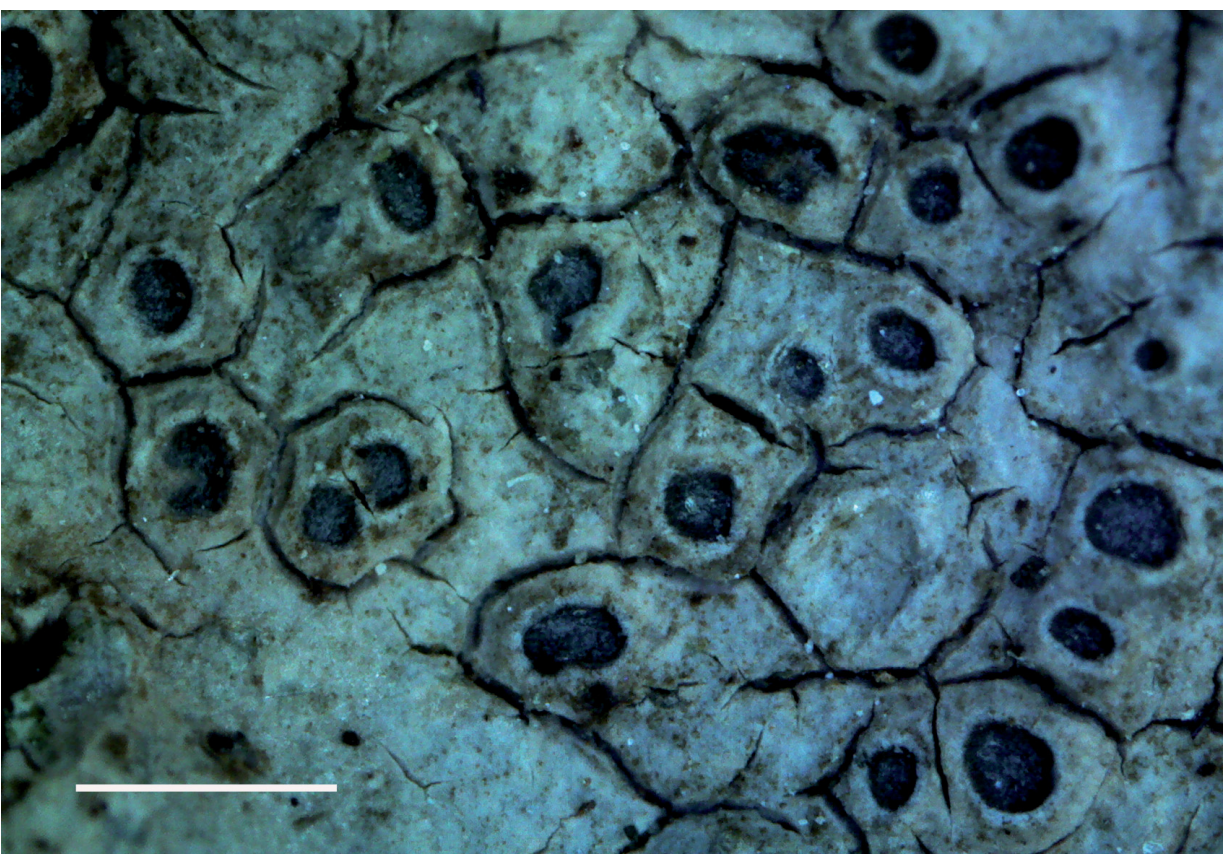

Fig. 2. Aspicilia pseudovulcanica (holotype, KoLRI 010391), general habit. Scale $1 \mathrm{~mm}$.

(Photo: S. Y. Kondratyuk). 
sp. Leg.: Wang, X. Y., Jeon, H. S., Lü, L. and Ryu, J. A. (100584), 26.05.2010 (KoLRI 012338 sub Aspicilia). - Gangwon-do, Chuncheon-si, Buksan-myeon, nearby Road of Soyang dam, on rock. Lat.: $37^{\circ} 59^{\prime} 48.89^{\prime \prime}$ N, Long.: $127^{\circ} 49^{\prime} 9.13^{\prime \prime}$ E, Alt.: ca 539 m a.s.l. Leg.: Jayalal, R. U. G., Park, J. S. and Woo, J.-J. (141375), 14.07.2014 (KoLRI 023829).

Aspicilia subepiglypta S. Y. Kondr., L. Lőkös et J.-S. Hur, sp. nov.

(Fig. 3)

MycoBank nr.: MB 819352.

Similar to Aspicilia epiglypta, but differs in having not zonated thallus, less number of apothecia per areolae, larger apothecia, different thalline margin, narrower paraphyses towards the tips, smaller ascospores, and slightly shorter conidia.

Type: Republic of Korea. Jeollanam-do Prov., Jindo-gun County, Jeob-do Island, on rock, growing together with Lichenothelia sp. and Buellia sp. Lat.: $34^{\circ} 23^{\prime} 41.14$ " N, Long.: $126^{\circ} 18^{\prime} 8.80^{\prime \prime}$ E, Alt.: ca 1 m a.s.l. Leg.: Wang, X. Y. and Ryu, J. A. (110495), 03.06.2011 (holotype: KoLRI 013539).

Thallus to 3-5 cm across, but probably forms much larger aggregations, areolate, white-greyish or light grey to grey-brownish, especially in peripheral zone; $\mathrm{K}+$ yellow becoming blood red later; hypothallus black well developed [100438]; areolae $0.4-0.7(-1.2) \mathrm{mm}$ across, very thick (to $0.2-0.4 \mathrm{~mm}$ ); after keeping in herbarium becomes somewhat yellowish; algal zone $\mathrm{K}+$ yellow washing out in solution later with red or rusty crystals, reaction very fast. Hypothallus as dark grey line, 0.6-1 mm wide, rarely observed, while sometimes (specimen 100438) well developed to $1 \mathrm{~mm}$ width as dark grey or greyish dark brown or greyishblackish in the outermost narrow portion.

Apothecia $0.2-0.3(-0.5) \mathrm{mm}$ diam./across, very variegated, (1-)3-5(-8) per areole, very irregular in shape, totally immersed into the thallus, aspicilioid, disc at the same level with thalline areole level; hymenium to 90-100 $\mu \mathrm{m}$ tall; epihymenium dull or dirty brown, $\mathrm{K}$ - brownish, $\mathrm{N}+$ greenish; asci 8-spored; ascospores hyaline, simple, rounded or slightly elongated, ascospores (13-)16-20 (-22) $\times$ (7-)8-12 $\mu \mathrm{m}$; conidia cylindrical, straight, long and narrow, 15-20 $\times 0.7-0.9 \mu \mathrm{m}$.

Chemistry: Containing norstictic acid (HPLC).

Ecology: Growing on siliceous rocks, from coastal zone to high localities in mountains.

Distribution: So far known from scattered localities of South Korea.

Etymology: It is named after its similarities with the species Aspicilia epiglypta (Nyl.) Hue.

Taxonomic notes: Aspicilia subepiglypta is similar to A. epiglypta in having dark olive green epihymenium, $\mathrm{N}+$ intensifying in bright green, in having 
norstictic acid, It seems to be the rarest of the trio including $A$. cinerea and $A$. intermutans, which differs principally in conidial and ascospores size, lacks the yellow tinge, has small number of apothecia (2-5, rarely single) per areolae, has small apothecia $(0.2-0.3(-0.5$ or -1$) \mathrm{mm}$ diam.), species growing on schistose and granite rocks, maritime, often in sunny, nutrient rich situations, but differs in having not zonated thallus (vs. usually markedly zonate at the margin, sometimes to $15 \mathrm{~mm}$ ), in the lack of thalline margin (vs. thalline margin raised, thick, angular-indented or convoluted, persistent), in having smaller ascospores ((13-) $16-20(-22) \times(7-) 8-12 \mu \mathrm{m}$ vs. $20-25 \times 12-15 \mu \mathrm{m})$, and slightly shorter conidia (15-20 $\times 0.7-0.9 \mu \mathrm{m}$ vs. $15-28 \times 1 \mu \mathrm{m})$.

Aspicilia subepiglypta is similar to $A$. adamanticola Hue, an Eastern Asian taxon, but differs in having somewhat shorter and distinctly narrower ascospores $(16-20 \times 8-12 \mu \mathrm{m}$ vs. $16-22 \times 12-14 \mu \mathrm{m})$, and longer conidia $(15-20 \times 0.7-0.9$ $\mu \mathrm{m}$ vs. $14-16 \times 0.6-0.8 \mu \mathrm{m})$.

Aspicilia subepiglypta is similar to the widely distributed Aspicilia cinerea, but differs in having longer conidia (15-20 $\times 0.7-0.9 \mu \mathrm{m}$ vs. $11-16 \times 1 \mu \mathrm{m})$.

Additional specimens examined: Republic of Korea. Gyeongsangnam-do, Hamyang-gun, Seosang-myeon, Mt Baekunsan, on rock, growing together with

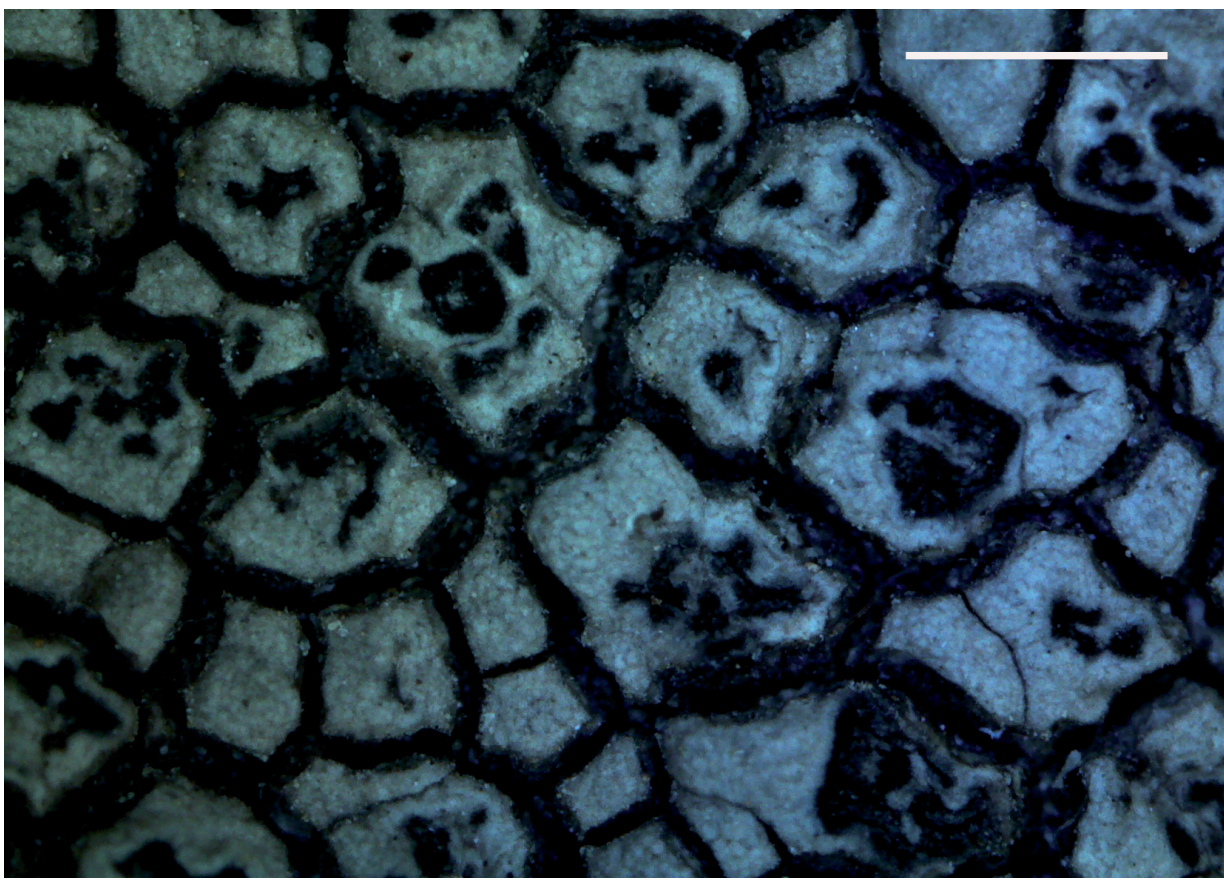

Fig. 3. Aspicilia subepiglypta (holotype, KoLRI 013539), general habit. Scale $1 \mathrm{~mm}$. (Photo: S. Y. Kondratyuk). 
Sarcogyne privigna, Aspicilia is partly damaged by Lichenostigma sp., Lat.: $35^{\circ} 36^{\prime}$ 36.8” N, Long.: $127^{\circ} 39^{\prime} 37.4$ ” E, Alt.: ca 903 m a.s.l. Leg.: Wang, X. Y., Jeon, H. S., Han, G. S. (100438), 24.06.2010 (KoLRI 012059 sub Aspicilia). - Gangwondo, Jeongseon-gun, Buk-myeon, Mt Bannonsan, on rock, growing together with Scoliciosporum chlorococcum. Lat.: $37^{\circ} 26^{\prime} 37.1^{\prime \prime}$ N, Long.: $128^{\circ} 45^{\prime} 29.4$ ' E, Alt.: ca 1,064 m a.s.l. Leg.: Wang, X. Y., Jeon, H. S., Lü, L. and Ryu, J. A. (100857-2), 28.05.2010 (KoLRI 012535-2 sub Aspicilia); the same locality, on rock, growing together with Scoliciosporum cf. umbrinum, Protoparmeliopsis aff. muralis damaged by lichenicolous fungus Rosellinula frustulosae (Vouaux) R. Sant.*, and Lobothallia sp. 100857-1 (KoLRI 012535-1 sub Aspicilia).

Aspicilia subgeographica S. Y. Kondr., L. Lőkös et J.-S. Hur, sp. nov. (Fig. 4)

MycoBank nr.: MB 819353.

Similar to Aspicilia geographica, but differs in having smaller conidia and larger ascospores.

Type: Republic of Korea. Jeollanam-do, Sinan-gun, Aphae-do, seaside, on rock growing together with Buellia cf. spuria, Lichenothelia sp. Lat.: $34^{\circ} 54^{\prime} 27.4^{\prime \prime}$ N, Long.: $126^{\circ} 18^{\prime} 58.7^{\prime \prime}$ E, Alt.: ca $8 \mathrm{~m}$ a.s.l. Leg.: Oh, S.-O., Park, J. S. and Woo, J.-J. (130359), 07.06.2013 (holotype: KoLRI 018704).

Thallus 3-5 cm diam., but may form larger aggregations, light grey or slightly brownish grey, distinctly areolate, upper surface matt, $\mathrm{K}$ - or $\mathrm{K}+$ very slowly purely yellow; areolae $0.5-1(-1.3) \mathrm{mm}$ diam./across, very irregular; rather thick, to $(0.2-) 0.4-0.5 \mathrm{~mm}$ thick in section; cortical layer to $20-30 \mu \mathrm{m}$ thick, somewhat indistinct in places; algal cells ca 16-18 $\mu \mathrm{m}$ diam.; medulla I-. Hypothallus only rarely present, usually thallus in peripheral zone somewhat excavated, undulating and uplifted and hypothallus absent / not observed, while sometimes black and filamentous (specimen 110813).

Apothecia to $0.9-1 \mathrm{~mm}$ diam./across and to $0.35 \mathrm{~mm}$ thick in section, lecanorine, with thalline margin to $0.1-0.25(-0.35) \mathrm{mm}$ wide or much wider, very often highly uplifted and covering disc to $50 \%$ or more (see Fig. 4); hymenium to $150 \mu \mathrm{m}$ tall, with oil droplets often richly; epihymenium dull greenish, $\mathrm{K}$ - becoming lighter and brownish, $\mathrm{N}+$ distinctly bluish; asci 8-spored; ascospores hyaline, simple, widely ellipsoid to spherical, (16-)19-22(-30) $\times(9-) 12-16(-17)$ $\mu \mathrm{m}$; conidiomata to $120 \mu \mathrm{m}$ diam., and to $130-140 \mu \mathrm{m}$ high; conidia cylindrical, straight, very short and narrow, 3.5-5.5 $\times 0.7-0.8(-1) \mu \mathrm{m}$.

Chemistry: Thallus $\mathrm{K}-$, medulla $\mathrm{K}+$ yellow to brownish yellow. Containing stictic acid (HPLC).

\footnotetext{
* Rosellinula frustulosae is reported for the first time from Korea.
} 
Ecology: Growing on siliceous rocks, from coastal zone to high localities in mountains.

Distribution: So far known from scattered localities of South Korea.

Etymology: It is named after its similarities with the species Aspicilia geographica Hue.

Taxonomic notes: Aspicilia subgeographica is similar to A. geographica, but differs in having smaller conidia and larger ascospores.

Aspicilia subgeographica is similar to $A$. adamanticola Hue, but differs in having very weak reaction of the thallus (vs. $\mathrm{K}+$ yellow becoming intense reddish later), in having larger algal cells, and longer conidia.

Aspicilia subgeographica is similar to $A$. cyanescens Owe-Larss. et A. Nordin, which is the only Californian Aspicilia species growing on bark or wood, but differs in having larger and lecanoroid apothecia $(0.9-1 \mathrm{~mm}$ vs. $0.2-0.6 \mathrm{~mm}$ diam., aspicilioid), lower hymenium (to $150 \mu \mathrm{m}$ vs. 130-200 $\mu \mathrm{m}$ high), shorter conidia $(3.5-5.5 \times 0.7-0.8(-1) \mu \mathrm{m}$ vs. $(12-) 16-27(-35) \times 0.6-1 \mu \mathrm{m})$, while ascospores are almost the same $((16-) 19-22(-30) \times(9-) 12-16(-17) \mu \mathrm{m}$ vs. (16-)18-25($31) \times(8-) 10-15(-17) \mu \mathrm{m})$.

Aspicilia subgeographica is similar to $A$. caesiocinerea (Malbr.) Arnold, but differs in having lecanorine apothecia (vs. aspicilioid, 1(-5) per areole), a hy-

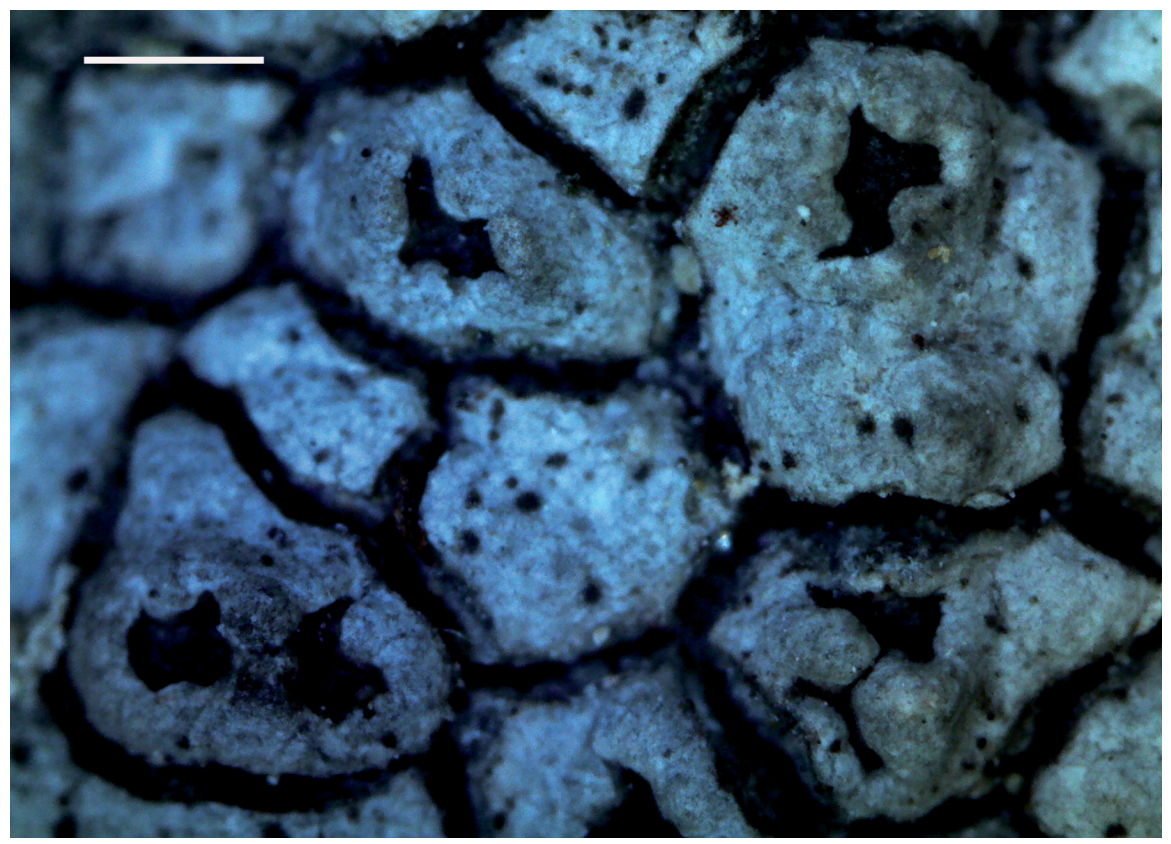

Fig. 4. Aspicilia subgeographica (holotype, KoLRI 018704), general habit. Scale $0.5 \mathrm{~mm}$. (Photo: S. Y. Kondratyuk). 
menium inspersed with oil, very wide ascospores $(19-22 \times 12-16 \mu \mathrm{m}$ vs. $20-25 \times$ $13-14 \mu \mathrm{m})$, shorter conidia $(3.5-5.5 \times 0.7-0.8 \mu \mathrm{m}$ vs. $6-10(-12) \times(0.8-) 1 \mu \mathrm{m})$, in having stictic acid, and in the lack of aspicilin.

Additional specimens examined: Republic of Korea. Jollabuk-do Prov., Gunsam-si city, Shinsi-do Island, on rock, growing together with Scoliciosporum jasonhurii, and Lichenothelia sp. Lat.: 35 49' 8.8” N, Long.: $126^{\circ} 27^{\prime}$ 55.8” E, Alt.: ca 19 m a.s.l. Leg.: Wang, X. Y. and Ryu, J. A. (110813), 22.10.2011 (KoLRI 013822 sub Aspicilia). - Jeollanam-do, Yeosu-si, Nam-myeon, Geumoh-do, Dumo-ri, Jickpo coast, on rock growing together with Buellia spuria. Lat.: $34^{\circ} 30^{\prime} 45.00^{\prime}$ N, Long.: $127^{\circ} 44^{\prime} 14.08^{\prime \prime}$ E; Alt.: ca 6 m a.s.l. Leg.: Jayalal, U., Park, J.-S. and Ryu, J. A. (120356), 26.04.2012 (KoLRI 015345 sub Aspicilia)*. - Jeollanam-do Prov., Sinan-gun Co., Bogil-do Island, on rock, growing together with Lecanora oreinoides, and Caloplaca aequata damaged by lichenicolous fungus Lichenostigma aff. bolacinae Nav.-Ros., Calat. et Hafellner. Lat.: 34 7' 51.72” N; Long: $126^{\circ} 30^{\prime}$ 43.68" E; Alt.: ca 19 m a.s.l. Leg.: Wang, X. Y. and Ryu, J. A. (110673), 23.06.2011 (KoLRI 013701 sub Lecanora oreinoides)**.

\section{Aspicilia subgoettweigensis S. Y. Kondr., L. Lőkös et J.-S. Hur, sp. nov.} (Fig. 5)

MycoBank nr.: MB 819354.

Similar to Aspicilia goettweigensis, but differs in having longer ascospores, and in the lack of norstictic and connorstictic acids, as well as in having lecanorine apothecia and much thicker subhymenium.

Type: Republic of Korea. Jeollanam-do, Sinan-gun, Bigeum-myeon, Imja-do, nearby wharf Jinri, on rock, growing together with Ramalina sp. Lat.: $35^{\circ} 5^{\prime} 21.1^{\prime \prime} \mathrm{N}$, Long.: $126^{\circ} 7^{\prime} 17.6^{\prime \prime} \mathrm{E}$, Alt.: ca $11 \mathrm{~m}$ a.s.l. Leg.: Oh, S.-O., Park, J.-S. and Woo, J.-J. (130234), 06.06.2013 (holotype: KoLRI 018579).

Thallus 3-5 cm diam., but may form larger aggregations, light grey or whitish grey to pure grey or lead-grey, areolate, areolae $0.3-1.5(-2.3) \mathrm{mm}$ diam./across, sometimes areoles well developed only in the centre while thallus only cracked in the peripheral portion, with portions to $3-4 \mathrm{~mm}$ across; with numerous apothecia in the centre, upper surface even, sometimes with small finger-like outgrowth to $0.15-0.2 \mathrm{~mm}$ diam, with somewhat darker uppermost portion; rather thick, to $(0.45-) 0.5-0.6(-0.8) \mathrm{mm}$ thick in section; cortical layer to (15-)20-30(-40) $\mu \mathrm{m}$ thick with distinct epinecral zone to $20 \mu \mathrm{m}$ thick sometimes, $\mathrm{K}$-; algal zone $\mathrm{K}+$ yellow, reaction rather weak; algal cells ca $15 \mu \mathrm{m}$ diam.; medulla I-; lower portion of thallus (medulla below algal zone) with numerous crystals not dissolving

\footnotetext{
* Specimen included with some hesitation since it contains stictic and thiophanic acids.

** Specimen was extremely small, but enough for getting DNA.
} 
in $\mathrm{K}$. Hypothecium well developed, black, to $0.5-0.8 \mathrm{~mm}$ wide in peripheral zone as entire circle around thallus.

Apothecia $0.4-0.8(-1) \mathrm{mm}$ diam./across and to $0.3-0.5 \mathrm{~mm}$ thick in section, lecanorine, 1-2(-4) per areole, at first immersed into thallus, but later thalline margin well distinct to $0.1-0.15 \mathrm{~mm}$ wide, rather thick, uplifted above thalline level, concolorous with thallus, pure grey; disc $0.2-0.5 \mathrm{~mm}$ diam./across, mainly concave, grey-black to bluish black, with somewhat greyish pruina or seem to be pruinose (but under larger magnification (more of $\times 100$ ) epruinose); in section thalline margin $90-100 \mu \mathrm{m}$ thick in lateral portion, well developed; true exciple to $40 \mu \mathrm{m}$ wide in lateral portion, hymenium to (100-)170-180 $\mu \mathrm{m}$ tall often with oil droplets; epihymenium dull or dirty brown, $\mathrm{K}$ - becoming lighter and brownish, $\mathrm{N}+$ bluish/greenish; subhymenium to $100 \mu \mathrm{m}$ thick, with oil droplets to $3 \mu \mathrm{m}$ diam., somewhat more greyish than hymenium; paraphyses to $4-5(-6) \mu \mathrm{m}$ wide, brownish and moniliform towards the tips; asci 8-spored; ascospores hyaline, simple, rounded or slightly elongated, ascospores (16-)19-23(-25)[-27?] $\times(9-)$ $11-14(-15)[-17] \mu \mathrm{m}$, spore wall to $0.7 \mu \mathrm{m}$ thick; conidia cylindrical, straight, long and narrow, (13-) $14-19 \times 0.7-0.8 \mu \mathrm{m}$.

Chemistry: Containing stictic acid (HPLC).

Ecology: Growing on siliceous rocks, from coastal zone to high localities in mountains.

Distribution: So far known from scattered localities of South Korea.

Etymology: It is named after its similarities with the species Aspicilia goettweigensis (Zahlbr.) Hue.

Taxonomic notes: Aspicilia subgoettweigensis is similar to Aspicilia goettweigensis, but differs in having longer ascospores, and in the lack of norstictic and connorstictic acids (see PAUKOV et al. 2016), as well as in having lecanorine apothecia and much thicker subhymenium.
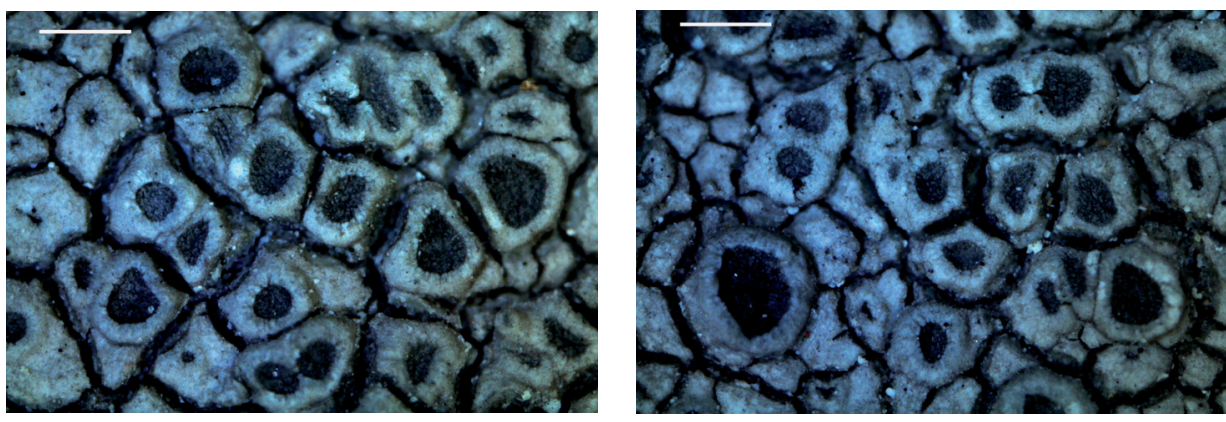

Fig. 5. Aspicilia subgoettweigensis (holotype, KoLRI 018579), general habit. Scale 0.5 mm. (Photo: S. Y. Kondratyuk). 
This taxon is accepted here in rather wide sense because it is so far heterogeneous. However, they are all characterised by having stictic acid in thallus, as well as large ascospores and long conidia. With further accumulation of specimens and molecular data on this group, it is probable that some of the specimens cited under this name will belong to different taxa in the future. Specimen 100588 (KoLRI 012341) having very light, almost white thallus and smaller apothecia is the most different from the others.

In general specimens of this taxon are very similar to $A$. cinerea based on measurements of ascospores and conidia, but differ in having only stictic acid, and the lack of norstictic acid, as well as in having different spot reactions.

Aspicilia subgoettweigensis is similar to $A$. pseudoabbasiana described above, but differs in having better developed hypothallus, seemingly pruinose dull greyish disc of apothecia, higher hymenium inspersed with oil, and in having somewhat wider ascospores.

Based on the rather thick $\mathrm{K}$ - thallus, medulla $\mathrm{K}+$ yellow, and almost the same areole and hymenium measurements, Aspicilia subgoettweigensis is similar to Japanese $A$. straminella Hue, but differs in having pure grey thallus (vs. strawyellow-greenish thallus), larger apothecia (0.4-0.8 $\mathrm{mm}$ vs. $0.2-0.4 \mathrm{~mm}$ wide), $\mathrm{K}-$ epihymenium $(\mathrm{K}+$ blue $)$, larger ascospores $(16-) 19-25(-26) \times(9-) 10-13(-15)$ vs. $16-20 \times(10-) 11-14(-15) \mu \mathrm{m}$ or to $10-11 \mu \mathrm{m}$ diam. if spherical ), and narrower ascospore wall (to $0.7 \mu \mathrm{m}$ vs. to $1.5 \mu \mathrm{m}$ thick). Unfortunately data on conidia and conidiomata of $A$. straminella are so far missing.

Based on its description, Aspicilia subgoettweigensis is similar to A. umbrinella Hue, but differs in having negative iodine reaction of medulla, as well as in having grey thallus, larger thalline areoles, higher hymenium, and weak $\mathrm{K}+$ yellow reaction of medulla. Unfortunately, data on the conidia of $A$. umbrinella are so far missing too.

In the key of "Lichen flora of the Greater Sonoran Desert region" this material can be keyed to Aspicilia fumosa Owe-Larss. et A. Nordin. In this paper it was mentioned that type specimens of $A$. fumosa were analysed for DNA (ITS), and it shows similarities to $A$. glaucopsina (Nyl.) Hue and $A$. phaea Owe-Larss. et A. Nordin (Owe-LaRsson et al. 2004). However, results of sequencing of these three species are still not available for wide access and cannot be included in our comparison. A. subgoettweigensis is similar to A. fumosa in having similar thick thallus, similar size of apothecia and often elevated fertile areoles, however it differs in having lighter and only greyish thallus (vs. partly brown-grey to olive-grey or light brown), either aspicilioid or lecanorine apothecia (vs. only aspicilioid), in having thalline margin concolorous with thallus (not becoming darker of thallus), while measurements of ascospores and conidia partly overlap. 
Additional specimens examined: Republic of Korea. Jeollanam-do, Yeosu-si, Samsan-myeon, Geomun-do Island, on rock, growing together with Buellia stellulata (Taylor) Mudd. Lat.: $34^{\circ} 0$ ' 39.0” N, Long.: $127^{\circ} 19^{\prime} 2.7^{\prime}$ E, Alt.: 8 m a.s.l. Leg.: Hur, J.-S. (070103), 24.03.2007 (KoLRI 007090). - Gangwon-do, Chuncheon-si, Buksanmyeon, Mt Maebong, Jogyo-ri, on rock, growing together with Melanophloaea coreana and Scoliciosporum sp., and overgrown by Scoliciosporum sp. in parts. Lat.: $37^{\circ}$ 54' 38.28” N, Long.: $127^{\circ} 58^{\prime}$ 54.48” E, Alt.: ca 610 m a.s.l. Leg.: Wang, X. Y., Jeon, H. S., Lü, L. and Ryu, J. A. (100588), 26.05.2010 (KoLRI 012341 sub Aspicilia). Jeollanam-do, Wando-gun, Saengil-myeon, Saengil-do, Geumdok-ri coast, on rock, growing together with Rinodina confragosa, Buellia stellulata and Lecanora oreinoides, as well as species of the genera Aspicilia, Xanthoparmelia and Ramalina. Lat.: $34^{\circ} 20^{\prime}$ 2.02” N, Long.: $126^{\circ} 57^{\prime} 51.02^{\prime \prime}$ E, Alt.: ca 7 m a.s.l. Leg.: Jayalal, U., Park, J.-S. and Ryu, J. A. (120188), 18.04.2012 (KoLRI 014782 sub Aspicilia). - Incheon, Ongjingun, Deokjeok-myeon, Deokjeok-do, Seopori wharf, on rock, Aspicilia damaged in parts by lichenicolous fungus Cercidospora sp. Lat.: $37^{\circ} 12^{\prime} 45.09^{\prime}$ N, Long.: $126^{\circ}$ 6' 44.05" E, Alt.: ca $1 \mathrm{~m}$ a.s.l. Leg.: Oh, S.-O. and Park, J.-S. (130489), 14.06.2013 (KoLRI 018834). - *Jeju-do, Jeju-si, Chuja-do, Chuja-myeon, Mt Dondae, Yecho-ri, on rock growing together with Lecanora lojkaehugoi, Candelariella corallina, Buellia and Ramalina spp. Lat.: $33^{\circ} 56^{\prime} 53.9^{\prime \prime}$ N, Long.: $126^{\circ} 19^{\prime} 26.7^{\prime \prime}$ E, Alt.: ca $164 \mathrm{~m}$ a.s.l. Leg.: Lőkös, L. (140756-3), 20.06.2014 (KoLRI 023232 sub Aspicilia).

Aspicilia submamillata S. Y. Kondr., L. Lőkös et J.-S. Hur, sp. nov.

(Fig. 6)

MycoBank nr.: MB 819355.

Similar to Aspicilia mamillata, but differs in having narrower ascospores.

Type: Republic of Korea. Gangwon-do, Yangyang-gun, Seo-myeon, Galjeongokbong, on rock. Lat.: $37^{\circ} 52^{\prime} 52.8^{\prime \prime} \mathrm{N}$, Long.: $128^{\circ} 26^{\prime} 50.9^{\prime \prime} \mathrm{E}$, Alt.: ca 1,101 m a.s.l. Leg.: Joshi, Y., Wang, X. Y. and Ryu, J. A. (090631), 22.05.2009 (holotype: KoLRI 010299).

Thallus more than $10 \mathrm{~cm}$ diam./across, white to dull white, light grey or greenish grey in places, distinctly areolate; areolae (0.5-)0.7-1.2(-2) mm diam./ across in the centre, while in peripheral zone not so well developed and not so distinguished; rather thick, to $0.5 \mathrm{~mm}$ thick in section; algal cells to $18 \mu \mathrm{m}$ diam.; medulla I-. Hypothallus not developed, or not observed.

Apothecia to $0.4-1(-1.3) \mathrm{mm}$ diam./across and to $0.2-0.25 \mathrm{~mm}$ thick in section, cryptolecanorine, 1-2 per areole, with well developed, entire, somewhat

\footnotetext{
* Specimen included with some hesitation since chemical and molecular data were not checked for this taxon.
} 
lighter thallus, whitish; disc seems to be with white pruina, but at larger magnification (more than $\times 100$ ) epruinose, matt, grey or brownish grey (not black); immersed into thallus; hymenium (90-)120-140 $\mu \mathrm{m}$ tall, with often abundant oil droplets; epihymenium green dark brown, $\mathrm{K}$ - becoming lighter and brownish, $\mathrm{N}+$ bluish; subhymenium to $30-50 \mu \mathrm{m}$ thick, with oil droplets to 3-4 $\mu \mathrm{m}$ diam.; asci 8-spored; ascospores hyaline, simple, widely ellipsoid to spherical, (15-)20-25(-27) × (7-)10-12(-14) $\mu \mathrm{m}$; ascospore wall to $1 \mu \mathrm{m}$ thick.

Conidiomata and conidia not seen.

Chemistry: Thallus $\mathrm{K}$ - or $\mathrm{K}+$ yellow, reaction very slow and weak; medulla $\mathrm{K}$ - or $\mathrm{K}+$ yellow. No substances detected or only stictic acid is present (HPLC).

Ecology: Growing on siliceous rocks, from coastal zone to high localities in mountains.

Distribution: So far known from scattered localities of South Korea.

Etymology: It is named after similarities with the species Aspicilia mamillata Räsänen.

Taxonomic notes: This species is characterised by having areolate thallus without well developed hypothallus, concave aspicilioid apothecia, where disc

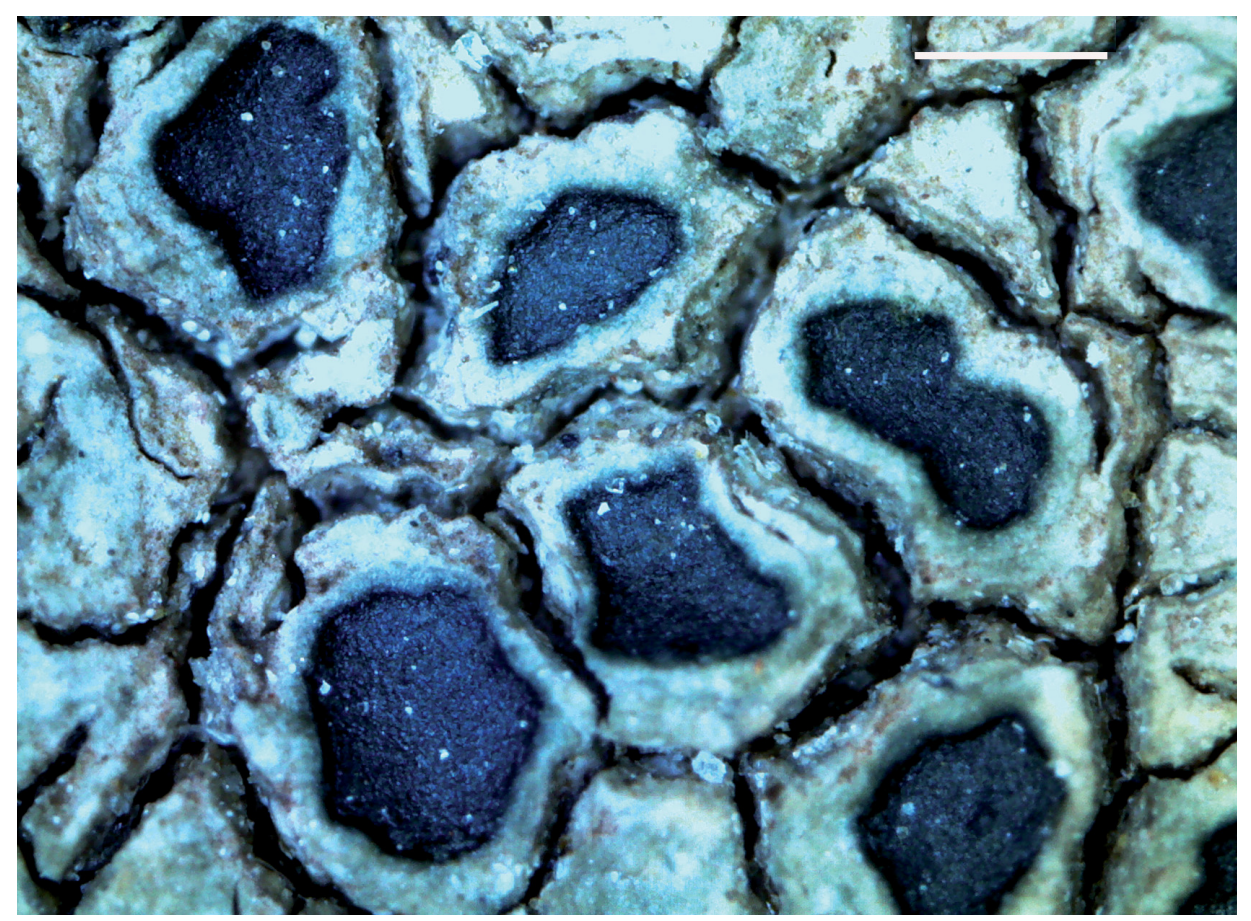

Fig. 6. Aspicilia submamillata (holotype, KoLRI 010299), general habit. Scale $0.5 \mathrm{~mm}$. (Photo: S. Y. Kondratyuk). 
often seem to be pruinose, medium high hymenium inspersed with oil, and rather long and medium wide ascospores.

Aspicilia submamillata is similar to $A$. mamillata, but differs in having narrower ascospores*.

Additional specimens examined: Republic of Korea. Jeollanam-do, Guryegun, Jirisan Mts, Masan-myeon, Nogodan-Yeon baceon, on rock. Lat.: 35 $17^{\prime}$ 50.3” N, Long.: $127^{\circ} 33^{\prime} 11.9^{\prime}$ E, Alt.: ca 1,364 m a.s.l. Leg.: Joshi, Y., Wang, X. Y. and Hur, J. Y. (091073), 13.10.2009 (KoLRI 010540); the same locality, 091096 (KoLRI 011146). - Gyeongsangnam-do, Hamyang-gun, Macheon-myeon, Mt Baekun, on rock. Lat.: $35^{\circ} 38^{\prime} 22.5^{\prime \prime} \mathrm{N}$, Long.: $127^{\circ} 37^{\prime} 23.2^{\prime \prime}$ E, Alt.: ca 1,058 m a.s.l. Leg.: Woo, J.-J., Park, G. S. and Oh, S.-O. (150737), 04.07.2015 (KoLRI 036046).**

New name and new combination

Aspicilia abbasiana S. Y. Kondr., L. Lőkös, Ismayil et Guo, nom. nov. - MycoBank nr.: MB 819356. - Synonym: Aspicilia volcanica Ismayil, A. Abbas et S. P. Guo, Mycotaxon 130: 545 (2015), nom. illeg. (Code 53.3), non Aspicilia vulcanica Hue.

Rimularia geumodoensis (S. Y. Kondr., L. Lőkös et J.-S. Hur) S. Y. Kondr., L. Lőkös et J.-S. Hur, comb. nov. - MycoBank nr.: MB 819357. - Basionym: Aspicilia geumodoensis S. Y. Kondr., L. Lőkös et J.-S. Hur, in Kondratyuk et al. Acta Bot. Hung. 58(3-4): 326 (2016).

Specimens of Rimularia geumodoensis examined: Republic of Korea. Jeollanam-do, Yeosu-si, Nam-myeon, Geumo-do, Simjang-ri, on rock, growing together with Lepraria and Endocarpon spp. Lat.: 34 31' 19.7' N, Long.: $127^{\circ} 43^{\prime} 52.1^{\prime \prime}$ E, Alt.: ca $51 \mathrm{~m}$ a.s.l. Leg.: Kondratyuk, S. Y. (160406), 10.06.2016 (holotype: KoLRI 038551); the same locality, growing together with Pyxine, Lepraria and Caloplaca sp., (160418), (isotype: KoLRI 038563); the same locality, growing together with Lecania, Lepraria and Endocarpon sp., (160416), (isotype: KoLRI 038561). - Gangwon-do, Chuncheon-si, Buksan-myeon, Mt Maebongsan, Jogyori, on rock. Lat.: $37^{\circ} 54^{\prime} 54.24^{\prime \prime} \mathrm{N}$, Long.: $127^{\circ} 59^{\prime} 1.86^{\prime}$ E, Alt.: ca $705 \mathrm{~m}$ a.s.l. Leg.: Wang, X. Y., Jeon, H. S., Lü, L. and Ryu, J. A. (100632), 26.05.2010 (KoLRI 012373). - Gangwon-do, Sokcho-si, Mt Seoraksan, on rock, Rimularia geumodoensis damaged by lichenicolous fungus Phaeospora peregrina (Flot.) Arnold***. Lat.: $38^{\circ}$ 9' 58.9” N, Long.: $128^{\circ} 27^{\prime} 16.0^{\prime \prime}$ E, Alt.: ca $463 \mathrm{~m}$ a.s.l. Leg.: Joshi, Y., Wang, X. Y. and Ryu, J. A. (090763), 22.05.2009 (KoLRI 010435).

\footnotetext{
* Unfortunately original description of $A$. mamillata is rather pure, no measurements on elements of thallus or apothecia are provided.

** Specimen included with some hesitation, it may belong to another separate taxon.

*** Phaeospora peregrina is reported for the first time from Korea.
} 
As it is seen from the phylogenetic tree of the genus Aspicilia s. str. (Fig. 7) taxa with stictic acid, i.e. $A$. pseudoabbasiana, $A$. pseudovulcanica, $A$. subgeographica, A. subgoettweigensis, and $A$. submamillata are members of the separate phylogenetic branch. Taxa containing norstictic acid, i.e. $A$. cinerea, A. blastidiosa, and A. subepiglypta are members of the second branch within the Aspicilia s. str. branch of the phylogenetic tree.

\section{Key to aspicilioid lichens of Korean and Eastern Asian region*}

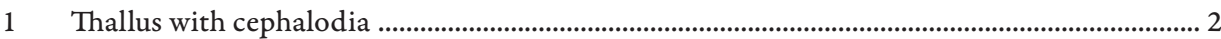

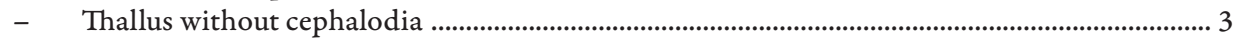

2 Areoles 0.6-1.5(-2) mm across; ascospores 10-12 $\times 5-6 \mu \mathrm{m}$................. (Aspicilia cremicolor)

- Areoles 0.3-0.5 mm across; ascospores 14-20 $\times$ 8-10 $\mu \mathrm{m}$........................... (Aspicilia tephroda)

3 Thallus effusely isidiate or granular sorediate. Apothecia usually absent

Circinaria leprosescens

Thallus without isidia or soredia; Apothecia usually present .......................................................... 4

Thallus $\mathrm{C}+\mathrm{red}$......................................................................................................................... 5

Thallus C- ..............................................................................................................................

5 Thallus of scattered areoles divided by well distinct black hypothallus; isidia $0.15-0.25 \mathrm{~mm}$ wide and to $0.5 \mathrm{~mm}$ high; soralia whitish $0.2-0.5 \mathrm{~mm}$ wide; apothecia $0.5-1.2 \mathrm{~mm}$ diam. (including thalline margin to $0.1-0.3 \mathrm{~mm}$ wide; ascospores $(14-) 15.5-25(-30) \times(9-) 10.5-$ $12.5(-14) \mu \mathrm{m}$

Rimularia gibbosa

- Thallus rimose-areolate; hypothallus not distinct or absent 6

6 Thallus with small soralia to $0.1 \mathrm{~mm}$ diam., and isidia $(0.05-) 0.1(-0.15) \mathrm{mm}$ diam., and to 0.2 $\mathrm{mm}$ high, erect or rounded; thalline areoles $0.3-0.7 \mathrm{~mm}$ across; apothecia $0.2-0.4 \mathrm{~mm}$ diam.; ascospores (11-) 12.5-20(-22) $\times(7-) 8-11.5(-13) \mu \mathrm{m}$

(Rimularia badioatra)

- Thallus without soralia and isidia; thalline areoles $0.7-1.3(-1.7) \mathrm{mm}$ diam./across; apothecia 0.4-0.7 mm diam.; ascospores (11-)12.5-20(-22) $\times(7-) 8-11.5(-13) \mu \mathrm{m}$; Thallus $\mathrm{K}+$ yellow

Rimularia geumodoensis

7 Medulla I+ blue Aspicilia umbrinella

- Medulla I-

8 Thallus and/or medulla $\mathrm{K}+$ red, or $\mathrm{K}+$ yellow then red or orange, or $\mathrm{K}+$ yellow; norstictic or stictic acid present

- Thallus K-, while medulla can be K+ weak yellow; no substances detected or stictic acid present . 28

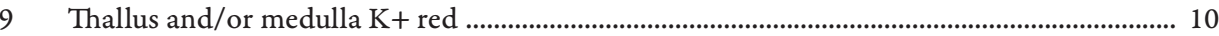

- Thallus and/or medulla $\mathrm{K}+$ yellow then red, or $\mathrm{K}+$ yellow ......................................................... 14

$10 \quad$ Thallus $\mathrm{K}+\mathrm{red}$.................................................................................................................. 11

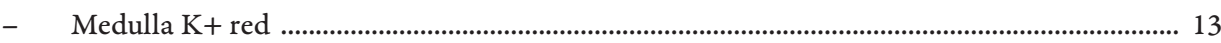

11 Ascospores 8-10 $\times 3-6 \mu \mathrm{m}$; conidia 10-12 $\times 1 \mu \mathrm{m}$............................... Aspicilia microsporeta

- Ascospores larger, conidia various .............................................................................................. 12

12 Conidia 11-16 $\times 1 \mu \mathrm{m}$; ascospores $12-22 \times 6-13 \mu \mathrm{m}$..................................... Aspicilia cinerea

- Conidia 15-20 $\times$ 0.7-0.9 $\mu \mathrm{m}$; ascospores 16-20 $\times$ 8-12 $\mu \mathrm{m}$.................. Aspicilia subepiglypta

13 Ascospores 19-24 $\times 12-14 \mu \mathrm{m}$; conidia 10-12 $\times 0.5-0.6 \mu \mathrm{m}$....................... Aspicilia fauriana

- Ascospores narrower, 17-20 × 7-8(-9) $\mu \mathrm{m}$; conidia unknown ....................... Aspicilia leucera

\footnotetext{
* Species known only from Japan or other neighbouring territories are given in brackets.
} 


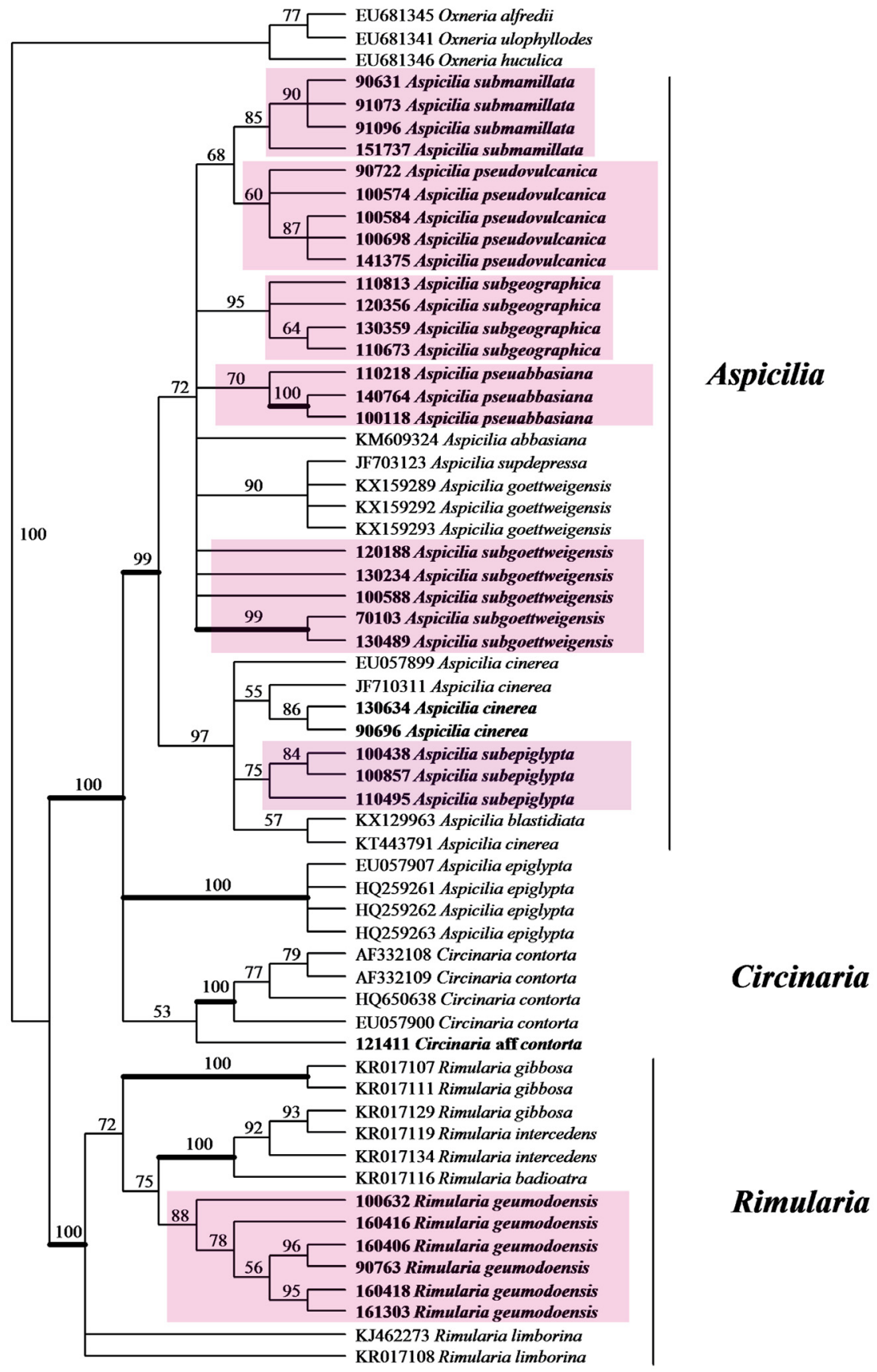

Fig. 7. Phylogenetic tree of aspicilioid lichens based on ITS nr DNA sequences. 
14 Thallus and/or medulla $\mathrm{K}+$ yellow then red or orange ............................................................. 15

- Thallus and/or medulla K+ yellow ...................................................................................... 24

15 Thallus seem to be placodioid, 0.5-0.6 mm thick; ascospores narrow, 14-24 $\times 8-9 \mu \mathrm{m}$ [or 16 $\times$ 6-7 $\mu \mathrm{m}]$; conidia 11-14 $\times 1 \mu \mathrm{m}$................................................................. Aspicilia stellata

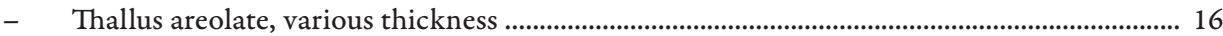

16 Thallus to $0.4-0.8 \mathrm{~mm}$ thick ................................................................................................. 17

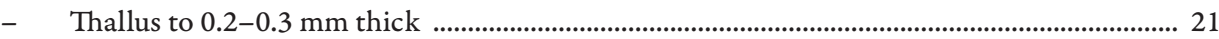

17 Ascospores broader, $10 \mu$ m wide ........................................................................................ 18

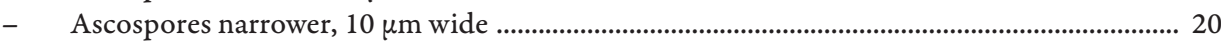

18 Conidia longer, $14 \mu \mathrm{m}$ long ..................................................................................................... 19

- Conidia (8-)9-14(-17) $\times 0.8-1 \mu \mathrm{m}$............................................................... (Aspicilia pacifica)

19 Conidia $14-16 \times 0.6-0.8 \mu \mathrm{m}$; ascospores $16-22 \times 12-14 \mu \mathrm{m}$; thallus $c a$ 0.2-0.4 mm thick .... Aspicilia adamanticola

- Conidia 14-22 $\times 0.7 \mu \mathrm{m}$; ascospores $16-19 \times 10-13(-14) \mu \mathrm{m}$; thallus ca 0.4-0.6 mm thick .. .................................................................................................... Aspicilia verrucigera

20 Apothecia 0.3-0.5 mm diam.; ascospores narrow 16-20 × 6-7 $\mu \mathrm{m}$.......... Aspicilia stenospora Apothecia to $1.5 \mathrm{~mm}$ diam.; ascospores wider, $15-20 \times 9-10 \mu \mathrm{m}$.................... Aspicilia excerta

21 Ascospore wall to $2 \mu \mathrm{m}$ thick ................................................................. (Aspicilia inaequata)

- Ascospore wall narrower, $2 \mu$ m thick .................................................................................... 22

22 Thallus becoming verruculose [areoles to $1.5-3 \mathrm{~mm}$ across] in the centre; ascospores narrow, 16-18 $\times 7-8 \mu \mathrm{m}$; conidia very short $4-5 \times 0.5-0.6 \mu \mathrm{m}$.......................... Aspicilia dimorphodes

- Thallus more or less areolate; conidia unknown, ascospores wider ......................................... 23

23 Thallus dull white; ascospores 16-22 × 8-10 $\mu \mathrm{m}$............................... Aspicilia chinnampoana

- Thallus yellowish-brownish to bluish-greyish; ascospores 13-24 × 10-12 $\mu \mathrm{m}$

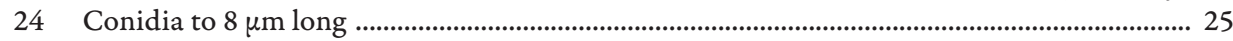

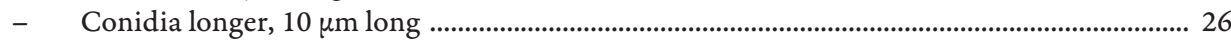

25 Conidia 6-7.5 $\times 1 \mu \mathrm{m}$; ascospores narrow, 10-12 $\times 5-6 \mu \mathrm{m}$................... Aspicilia geographica

- Conidia 3.5-5.5 $\times 0.7-0.8 \mu \mathrm{m}$; ascospores much larger, $19-22 \times 12-16 \mu \mathrm{m}$

Aspicilia subgeographica

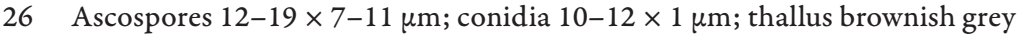

Aspicilia tumens

- Ascospores 18-23 × 11-14 $\mu \mathrm{m}$; conidia (13-)15-18(-19) $\times 0.7-1 \mu \mathrm{m}$; thallus dark grey ... 27

27 Thallus $\mathrm{K}$-, to $0.5(-0.8) \mathrm{mm}$ thick; hypothallus well developed; apothecia to $0.5(-0.8) \mathrm{mm}$ diam.; apothecium disc greyish; hymenium 140-170 $\mu \mathrm{m}$ high inspersed with oil

Aspicilia subgoettweigensis

- $\quad$ Thallus $\mathrm{K}+$ yellow, less than $0.4 \mathrm{~mm}$ thick; hypothallus absent; apothecia mainly more than 0.8 mm diam.; apothecium disc black; hymenium 110-140 $\mu \mathrm{m}$ high .... Aspicilia pseudoabbasiana

28 Thallus straw-yellow-greenish; medulla $\mathrm{K}+$ yellow; ascospore walls to $1.5 \mu \mathrm{m}$ thick

Aspicilia straminella

- $\quad$ Thallus white, grey to brownish without yellow colour; ascospore walls various .................. 29

29 Thallus rather thick, to $0.4(-0.8) \mathrm{mm}$ thick in section ........................................................... 30

- $\quad$ Thallus rather thin, to $0.2(-0.3) \mathrm{mm}$ thick in section .......................................................... 34

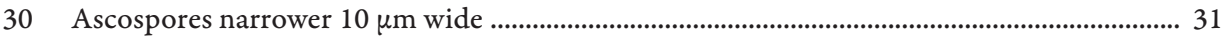

- Ascospores broader $10 \mu \mathrm{m}$ wide ......................................................................................................... 32

31 Conidia 10-15 $\times 1 \mu \mathrm{m}$; ascospores 14-16 $\times 6-7 \mu \mathrm{m}$............................. (Aspicilia aomoriana)

- Conidia unknown; ascospores 12-16 × 8-9 $\mu \mathrm{m}$........................................ (Aspicilia owaniana) 
32 Thallus placodioid, conidia 11-14 × $1 \mu \mathrm{m}$; ascospores wide, $16-20 \times 10-14 \mu \mathrm{m}$

Aspicilia asteria

_ Thallus areolate; conidia unknown ....................................................................................... 33

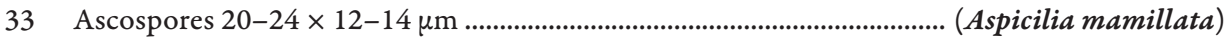

- Ascospores (15-)18-25(-27) $\times(7-) 10-13(-14) \mu \mathrm{m}$; apothecia 0.4-1 mm diam., disc seem to be pruinose (but not!); hymenium 120-140 $\mu \mathrm{m}$ high; hypothecium inspersed with oil

Aspicilia submamillata

34 Hymenium 100-140 $\mu \mathrm{m}$ high; ascospores narrow 7-12 $\mu \mathrm{m}$ wide 35

- Hymenium 140-180 $\mu \mathrm{m}$ high; ascospores much wider, 14-20-24 × 10-12-18 $\mu \mathrm{m}$ or to $12 \mu \mathrm{m}$ diam. if spherical (Aspicilia nitellina)

35 Ascospores narrow, (10-)17-20 × 7-10 $\mu \mathrm{m}$; apothecia 0.3-0.4 mm diam.

Aspicilia vulcanica

- $\quad$ Ascospores wider, 18-23(-25) $\times(9-) 10-12(-14) \mu \mathrm{m}$; apothecia 0.5-0.8 mm diam. Aspicilia subvulcanica

\section{CONCLUSIONS}

The first results of the molecular study of Aspicilia species from Korea show that we are still very far from understanding species diversity of this genus. Hue's and Nylander's taxa described more than a century ago from this region still need to be confirmed by fresh collections and molecular data.

Molecular study of a number of other floristical novelties for Korea, i.e. Aspicilia pacifica, Circinaria contorta, C. leprosescens and others selected hitherto only on the basis of morphological characters is still in progress. Their status will be discussed separately when results of DNA extraction and sequencing are available.

Acknowledgements - This work was supported by the Korea National Research Resource Centre Program, the Korean Forest Service Program (KNA 2012-2016) through the Korea National Arboretum, (for LL) the Hungarian Scientific Research Fund (OTKA K81232), and (for SK) in part by The Ministry of Education and Science of Ukraine (M/90-2015 and M/34-2016) and by Korean Brain Pool Program (161S-4-3-1659).

Összefoglaló: Az Aspicilia nemzetség taxonómiai revíziója során összesen 18 faj jelenlétét igazoltuk Korea területéről, ebből hat tudományra új fajt (Aspicilia pseudoabbasiana, $A$. pseudovulcanica, A. subepiglypta, A. subgeographica, A. subgoettweigensis, and A. submamillata) jelen dolgozatban írtunk le, illetve ismertettünk. Egy a taxonómiai nevezéktan szabályai alapján hibásan elnevezett fajnak (Aspicilia volcanica Ismayil, Abbas et Guo nom. illeg., non Aspicilia vulcanica Hue) új nevet adtunk (Aspicilia abbasiana), valamint az Aspicilia geumodoensis S. Y. Kondr., Lőkös et J.-S. Hur fajt egy másik nemzetségbe soroltuk át Rimularia geumodoensis néven. Kimutattuk, hogy az Aspicilia cf. pacifica, a Buellia coniops, a Circinaria contorta és a C. leprosescens zuzmófajok, továbbá a Lichenostigma bolacinae, a Phaeospora peregrina és a Rosellinula frustulosae zuzmólakó mikrogombafajok újak Korea zuzmóflórájára. Elkészítettük a koreai, illetve a kelet-ázsiai Aspicilia fajok határozókulcsát, melyet szintén itt közlünk. 


\section{REFERENCES}

Aptroot, A. and Moon, K. H. (2014): 114 new reports of microlichens from Korea, including the description of five new species, show that the microlichen flora is predominantly Eurasian. Herzogia 27(2): 347-365. https://doi.org/10.13158/heia.27.2.2014.347

Hue, A. (1912): Lichenes morphologice et anatomice disposuit (continuatio). - Nouv. Arch. Mus. hist. nat. Paris, sér. 5, 2: 1-120.

HuR, J.-S., KoH, Y. J. and Harada, H. (2005): A checklist of Korean lichens. - Lichenology 4(2): 65-95.

Ismayil, G., AвBAS, A. and Guo, S.-Y. (2015): Aspicilia volcanica, a new saxicolous lichen from Northeast China. - Mycotaxon 130: 543-548. https://doi.org/10.5248/130.543

IVANova, N. V. and HAFELLNER, J. (2002): Searching for the correct placement of Megaspora by use of ITS1, 5.8S and ITS2 rDNA sequence data. - Bibl. Lichenol. 82: 113-122.

Kondratyuk, S. Y., Kärnefelt, I., Thell, A., Elix, J. A., Kim, J., Kondratiuk, A. S. and Hur, J.-S. (2015a): Brownlielloideae, a new subfamily in the Teloschistaceae (Lecanoromycetes, Ascomycota). - Acta Bot. Hung. 57(3-4): 321-343. https://doi.org/10.1556/034.57.2015.3-4.6

Kondratyuk, S. Y., Kim, J. A., Yu, N.-H., Jeong, M.-H., Jang, S. H., Kondratiuk, A. S., ZAREI-DARKI, B. and HUR, J.-S. (2015b): Zeroviella, a new genus of xanthorioid lichens (Teloschistaceae, Ascomycota) proved by three gene phylogeny. - Ukr. Bot. Journal 72(6): 574-584. https://doi.org/10.15407/ukrbotj72.06.574

Kondratyuk, S. Y., Lökös, L., Kim, J. A., Kondratiuk, A. S., Jeong, M. H., Jang, S. H., $\mathrm{OH}, \mathrm{S} .-\mathrm{O}$. and HuR, J.-S. (2015c): Three new monotypic genera of the caloplacoid lichens (Teloschistaceae, lichen-forming Ascomycetes). - Mycobiology 43(3): 195-202. https://doi.org/10.5941/myco.2015.43.3.195

Kondratyuk, S. Y., Lökös, L., Kim, J. A., Kondratiuk, A. S., Jeong, M.-H., Jang, S. H., OH, S.-O. and HUR, J.-S. (2015d): New members of the Pertusariales (Ascomycota) proved by combined phylogenetic analysis. - Studia bot. hung. 46(2): 95-110.

https://doi.org/10.17110/studbot.2015.46.2.95

Kondratyuk, S. Y., LÖkÖs, L., Halda, J. P., Haji Moniri, M., FARKas, E., PARK, J. S., LeE, B. G., OH, S.-O. and HuR, J.-S. (2016a): New and noteworthy lichen-forming and lichenicolous fungi 4. - Acta Bot. Hung. 58(1-2): 75-136. https://doi.org/10.1556/034.58.2016.1-2.4

Kondratyuk, S. Y., LöKös, L., Halda, J. P., Upreti, D. K., Mishra, G. K., Haji Moniri, M., Farkas, E., Park, J. S., Lee, B. G., Liv, D., Woo, J.-J., Jayalal, R. G. U., Oh, S.-O. and HUR, J.-S. (2016b): New and noteworthy lichen-forming and lichenicolous fungi 5. - Acta Bot. Hung. 58(3-4): 319-396. https://doi.org/10.1556/abot.58.2016.3-4.7

Moon, K. H. (2013): Lichen-forming and lichenicolous fungi of Korea. - National Institute of Biological Resources, Korea, 139 pp.

Nordin, A., Tibell, L. and Owe-Larsson, B. R. (2007): A preliminary phylogeny of Aspicilia in relation to morphological and secondary product variation. - Bibl. Lichenol. 96: 247-266.

Owe-Larsson, B., Nordin, A. and Tibell, L. (2004): Aspicilia. - In: NASh, III, T. H., Gries, C. and Bungartz, F. (eds): Lichen flora of the Greater Sonoran Desert region. Vol. 3. Lichens Unlimited, Arizona State University, Tempe, pp. 61-108.

Paukov, A., Nordin, A., Tibell, L., Frolov, I. and Vondrák, J. (2016): Aspicilia goettweigensis (Megasporaceae, lichenized Ascomycetes) - a poorly known and overlooked species in Europe and Russia. - Nordic J. Bot., early view, online version.

https://doi.org/10.1111/njb.01222

Resl, P., Schneider, K., Westberg, M., Printzen, C., Palice, Z., Thor, G., Fryday, A., Mayrhofer, H. and Spribille, T. (2015): Diagnostics for a troubled backbone: test- 
ing topological hypotheses of trapelioid lichenized fungi in a large-scale phylogeny of Ostropomycetidae (Lecanoromycetes). - Fungal Divers. 73(1): 239-258.

https://doi.org/10.1007/s13225-015-0332-y

Roux, C., Nordin, A., Tibell, L. and Sohrabi, M. (2011): Some poorly known or new Aspicilia species from Pyrenees-Orientales (France). - Bull. Soc. Linn. Provence 14: 177-227.

Schmull, M., Miadeikowska, J., Pelzer, M., Stocker-Wörgötter, E., Hofstetter, V., Fraker, E., Hodkinson, B. P., Reeb, V., Kukwa, M., Lumbsch, H. T., Kauff, F. and Lutzoni, F. (2011): Phylogenetic affiliations of members of the heterogeneous lichenforming fungi of the genus Lecidea sensu Zahlbruckner (Lecanoromycetes, Ascomycota). Mycologia 103(5): 983-1003. https://doi.org/10.3852/10-234

Spribille, T., Resl, P., Ahti, T., Pérez-Ortega, S., Tønsberg, T., Mayrhofer, H. and Lumbsch, H. T. (2014): Molecular systematics of the wood-inhabiting, lichen-forming genus Xylographa (Baeomycetales, Ostropomycetidae) with eight new species. - Symb. Bot. Upsal. 37(1): 1-87.

(submitted: 10.10.2016, accepted 17.11.2016) 